\title{
IMPLEMENTATION OF GLOBAL COMPETENCY IN HIGHER EDUCATION
}

\author{
T. A. Anoshkova \\ Kyiv, National Technical University of Ukraine \\ "Kyiv Polytechnic Institute" \\ t.anoshkova@mail.ru
}

The article is devoted to the thorough characteristics of global competence as an important component of training young specialists. Globalization processes led to the irreversible changes in the modern society, opening the world borders and increasing the role of international communication. Such processes affected the higher education of numerous countries and created the concept of global education. The article describes global competency as the essential component of global education. There are several definitions of global competency, given by American, European and native scientists. The key competencies are determined on the basis of the research works of the scientists. The author gives general characteristic of these competencies in accordance with the emphasized approaches. The emphasis is placed on the understanding of cultural differences and intercultural communication with the leading role of foreign language in global education process. In the current article it is explained the connection between competencies acquired by students at the universities and the demands of the real-world labor market. The article also underlines the dominant position of a teacher in the successful acquirement of global competency by the students. It gives the examples of the pedagogical skills necessary for developing competencies in the context of global education.

Key words: global competency, global education, globalization, cultural differences, international communication, foreign language, higher education.

Introduction. Modern society is described as the constantly changing, affecting all spheres of human life. Economy, industry and culture are influenced by the informatization and globalization of the world, migration processes and intercultural relations.

One of the essential spheres of influence in up-to-date society is education. During the last few decades in many countries of the world and in Ukraine particularly the social paradigm has changed from industrial to informational. Education has developed regarding the integration and globalization processes, creating the unified information space. Such changes were so rapid that they created the necessity to improve all spheres of higher education since the existing systems did not correspond to the requirements of the modern world.

The important factor of the reconsideration of the main educational concepts in most countries is the expanding of the borders and the opportunities that are available to the youth. Training young specialists how to work in complicated and controversial conditions of the world globalization is the main task of global education.

Since Ukraine is one of European countries, it is affected by the above mentioned processes and intends to form the education essential for the modern world requirements the current articles proves its importance in the field of researching educational innovations.

Significant success in the implementation of global education basics is reached by American and European researchers and teachers. The goals of global education are achieved by acquiring of global competency. The lack of experience of Ukrainian higher academic institutions in this field can be compensated by the knowledge of other countries. 
That is why, the purpose of the article is to understand the notion of global competency itself and to analyze the implementation of this concept into the education programs of different countries.

The definition of global competency and its basic components. As we can find out from the experience, today the formation of educational goals takes place not at the state level but at the international, intercultural levels where basic education priorities and goals are proclaimed in international conventions and documents and become strategic goals of the international community. Today states form their educational policies aimed directly at integration to the international community.

European scientists consider that the acquirement of the knowledge and skills by young specialists is intended to improve their competency, intellectual and cultural development of the personality, forming the ability to respond to the changes of our time [3, p. 6].

In many countries of the world the education programs have already been changed in accordance with the basic competencies determined by the scientists. That's why it is necessary to define the concept of global competency and determine the basic competencies.

There are different definitions of the term global competency due to the research works of the numerous scientists. The US National Education Association refers to global competence as the acquisition of in-depth knowledge and understanding of international issues, an appreciation of an ability to learn and work with people from diverse linguistic and cultural backgrounds, proficiency in a foreign language, and skills to function productively in an interdependent world community $[4$, p. 1$]$.

Such definition of the concept somehow reflects the statements of the Ukrainian scientists, such as G. Nesen, O. Ovcharuk, G. Popova, V. Yahupov, V. Svystun, N. Avshenuk and others. They identify competency as the ability of the specialists to apply the acquired knowledge and skills and to reveal social qualities of the personality in the process of their professional activity [2, p. 2].

With the existence of the differences in understanding of global competency among scientists of the world we can regard the diversity of categories included in this concept by the researches.

Considering the changing demands of work, companies from one country employ workers from another, countries conclude agreements on import and export of goods, governments search for foreign investments, business is run via internet communication. Thus, one of the main tasks of modern education is to prepare our future workforce for international competition.

American students are aimed to develop such habits as responsibility, cooperation, tolerance and mere humanity. Based on these characteristics the US scientists distinguish four basic elements of global competency, these are:

- International awareness. This category includes the understanding of the world history, social, political and economic processes. It provides general awareness of the tendency to expand world boundaries and gives recognition on how individual affects others people or even nations and cultures.

- Intercultural understanding. This element is evolved as part of multicultural education and comprises knowledge of cultural differences and relations between races, accepting those differences and gaining opportunities from the cross-cultural communication. 
- Foreign language learning. It is supposed that one of the key categories which characterize global education is the fluency in at least one non-native language. It also develops cultural understanding and enhances communication skills.

- Competitive skills. The ability to produce innovative and creative thinking considering the economic, social and technological development of the globe permits to compete in the world market.

Analyzing different scientific researches other components can be added. In particular, English classical scholar John Raven separates such notions as the ability of self-learning, critical thinking, readiness to solve complex problems, ability to use innovations for reaching a goal, personal responsibility, ability to listen to others and to take into consideration the received information etc.

Hence, it is hard to list all the skills that globally competent graduates should have but there are two main capacities important for intercultural communication as well as for modern employers. One of them is adaptibility, which includes the capacity to find one`s own perspectives and to evaluate other's, considering a world growing cultural interaction and diversity. The other one is competitiveness in the severe conditions of the labor market. This implies the ability of globally competent specialist to analyze tendencies in the world economy, politics, religion and culture and to express his own views. Such competencies demand students to be able to listen and communicate with the help of non-native language, using up-to-date technologies.

Pedagogical aspect in global competency implementation. As we made sure, global competency is a multidimensional phenomenon though it is based upon the educational approach. And the key factor of this approach lies in the teacher's ability to explain his students the realities of the globalized world. Hence, the issue of the appropriate teacher's qualification becomes dominant.

American scientist Fernando Reimers separates three dimensions for a "teaching space" which are included in the definition of global competency [5, p. 3]. These are the following: the academic dimension, the action dimension and the ethical dimension. The first category comprises the profound knowledge in history, geography and global problems of humanity such as environmental protection, economic changes etc. It also includes the capability to think critically and creatively meeting the challenges of globalization. The second dimension is in charge of an action, that is, communication conducted with foreign language speakers individually or in groups. The third aspect develops a positive disposition towards cultural diversity, acknowledgement of global human values, respecting the differences and uniqueness of every nation. In its simplest form this competence represents the tolerate attitude toward the expression of human culture. In the highest, it provides recognition of the diversity in the cross-cultural context, cultural mobility and versatility, necessary for effective interpersonal relations in the multicultural society.

Professional development of a teacher provides that a specialist with a formed global competence possesses the knowledge about the subject in an international dimension and the global problems, concerning that subject; pedagogical skills in order to teach the students how to analyze the information from the original sources and to accept different points of view; the ability to educate students as responsible citizens of their local and at the same time of the global society.

The most effective source for the development of communicative competency lies in the intercourse with highly-qualified teachers during the educational process at the university and the communication with native speakers during the participation in 
exchange programs and distance learning. Learning to read in a foreign language contributes to the analysis of foreign texts and, therefore, gives access to the knowledge about certain society and its culture, and changes perception of global problems. The constructive interaction between students and teachers can be performed with the students' ability to understand the differences among the civilizations and the belief in their equal rights and opportunities. It is also hard to underestimate the role of extra-curriculum forms of education in obtaining global competencies. Teachers have to encourage students for the participation in videoconferences with students from foreign universities, summer camps, and international projects on solving the cross-cultural problems [1, p. 247].

Experts believe that creating conditions for acquiring necessary competences will support the productivity and competitive ability of the labor market; will decrease unemployment; will develop the environment for innovative changes in terms of global competitiveness. The acquirement of such competences is important for individual as they will contribute to forming of democratic society foundations; social understanding and justice; and respecting of human rights.

Conclusion. Hence, the information mentioned above characterizes the globalization processes of the modern societies which lead to irreversible changes in all spheres of human life. Young people have to be ready to meet the demands of the modern labor market, and business companies want to be sure that young specialists are sensitive to global changes, able to think critically and creatively.

Global competence is the ability to cooperate with people from diverse societies and cultures. As we understood, there is no unified list of competencies necessary for global education but it can be said for sure that one skill combines different approaches. That is the ability to be fluent in at least one foreign language including some knowledge of history and geography, political and cultural peculiarities of the country where this language is native. This skill enables student to communicate beyond the borders of his own country, to be aware of all the cultural and economic changes of the world and to meet the severe requirements of the marketplace.

Global competency as a multidimensional phenomenon requires the application of special pedagogical skills and knowledge for achievement ethical, academic and action competencies. The key approach in this process is the encouragement of students to participate in international scientific and research activities.

In conclusion, we can say that today the implementation of global competency in higher academic institutions is a world-wide tendency with Ukraine as one of the participants of this process. However, the world is constantly changing and scientists have to conduct further researches in the field of global education, analyze the experience of other countries and implement it in Ukrainian education.

\section{REFERENCES}

1. Авшенюк Н. Міжнародні підходи до обгрунтування глобальної компетентності вчителя [Електронний ресурс] / Наталія Авшенюк. - Режим доступу до ресурсу: http://lib.iitta.gov.ua/4037/1/Binder1.pdf.

2. Барко В. І. Аналіз наукових підходів до становлення поняття “професійна компетентність" сучасного фахівця [Електронний ресурс] / В. І. Барко // Вісник Національної академії Державної прикордонної служби України. - 2010. - Режим доступу до ресурсу: http://nbuv.gov.ua/j-pdf/Vnadps_2010_5_18.pdf.

3. Компетентнісний підхід у сучасній освіті: світовий досвід та українські перспективи / [Н. М. Бібік, Л. С. Ващенко, О. І. Локшина та ін.]. - Київ: К. І. С., 2004. - 112 с. 
4. Глобальна компетентність - вимога 21го століття [Електронний ресурс]

// Національна асоціація освіти, Вашингтон. - 2010. - Режим доступу до pecypcy: http://www.nea.org/assets/docs/HE/PB28A_Global_Competence11.pdf.

5. Реймерс Ф. Навчання глобальній компетенції [Електронний ресурс] / Фернандо Реймерс // Гарвардська вища школа освіти. - 2009. - Режим доступу до ресурсу: https://www.neafoundation.org

\section{REFERENCES}

1. Avshenyuk, N. (n.d.). International Approaches To Substantiation Of Teacher Global Competency. Retrieved from http://lib.iitta.gov.ua/4037/1/Binder1.pdf [In Ukrainian].

2. Barko, V. I. (2010). The analysis of scientific approaches to the formation of "Professional Competency" concept of modern specialist. Retrieved from http://nbuv.gov.ua/jpdf/Vnadps_2010_5_18.pdf [In Ukrainian].

3. Bibik, N. M. \& Vaschenko, L. S. (2004). Competency approach in modern education: world experience and Ukrainian perspectives. Retrieved from http://www.undp.org.ua/files/ua_33582maket_competence_ukr_ost.pdf. [In Ukrainian].

4. NEA Education Policy and Practice Department (2010). Global Competence Is a 21st Century Imperative. Retrieved from http//www.nea.org/assets/docs/HE/PB28A_Global_Competence11.pdf [In Ukrainian].

5. Reimers, F. (2009). Educating for Global Competency. Retrieved from https://www.neafoundation.org [In Ukrainian].

\section{Т. А. Аношкова. Впровадження глобальної компетентності у вищу освіту.}

Статтю присвячено вивченню глобальної компетентності, як важливої складової підготовки молодих фахівців. Процеси глобалізації призвели до невідворотних змін у сучасному суспільстві, відкриваючи світові кордони і збільшуючи роль міжнародного спілкування. Такі процеси вплинули на вищу освіту безлічі країн і створили концепцію глобального освіти. У статті описується глобальна компетентність, як ключовий компонент глобальної освіти. Надано декілька визначень поняття компетентності грунтуючись на роботах американських, європейських і вітчизняних учених. Виділено ключові компетентності, відповідно до проаналізованих наукових досліджень. Автор дає коротку характеристику основних компетентностей, спираючись на виділені підходи. Акцент зроблено на розуміння важливості культурних відмінностей і міжкультурної комунікації в процесі глобальної освіти, де іноземна мова посідає провідну позицію. У даній статті пояснюється зв'язок між компетентностями, набутими студентами в університеті та вимогами ринку праці у реальному світі. У статті також підкреслюється важливість ролі вчителя в успішному набутті глобальної компетенції студентами. Виділяють три виміри глобальної компетентності для професійного розвитку викладачів. Наводяться приклади педагогічних навичок, необхідних для розвитку компетентностей у контексті глобальної освіти.

Ключові слова: глобальна компетенція, глобальна освіта, глобалізація, культурні відмінності, міжнародне спілкування, іноземна мова, вища освіта.

\section{Т. А. Аношкова. Внедрение глобальной компетентности в высшее образование.}

Статья посвящена изучению глобальной компетентности, как важной составляющей подготовки молодых специалистов. Процессы глобализации привели к неотвратимым изменениям в современном обществе, открывая мировые границы и увеличивая роль международного общения. Такие процессы повлияли на высшее образование множества стран и создали концепцию глобального образования. В статье описывается глобальная компетентность, как ключевой компонент глобального образования. Дается несколько определений понятия компетентность. Выделены ключевые компетентности, основываясь на работах американских, европейских и отечественных ученых. Автор дает основные характеристики компетентностей, опираясь на выделенные подходы. Акцент сделан на понимании важности культурных различий и межкультурной коммуникации. В данной статье объясняется связь между компетенциями, приобретенными студентами в университетах и требованиями реального рынка труда. В статье также подчеркивается важность роли учителя в успешном приобретении глобальной компетенции студентами. Дается пример педагогических навыков, необходимых для развития компетентности в контексте глобального образования.

Ключевые слова: глобальная компетенция, глобальное образование, глобализация, культурные различия, международное общение, иностранный язык, высшее образование. 